\title{
Drop profile analysis tensiometry with drop bulk exchange to study the sequential and simultaneous adsorption of a mixed $\beta$-casein $/ \mathrm{C}_{12}$ DMPO system
}

\author{
Cs. Kotsmár • D. O. Grigoriev • A. V. Makievski • \\ J. K. Ferri • J. Krägel • R. Miller • H. Möhwald
}

Received: 31 December 2007 / Revised: 26 March 2008 / Accepted: 27 March 2008 / Published online: 29 May 2008

(C) The Author(s) 2008

\begin{abstract}
The formation of mixed protein/surfactant adsorption layers is studied by the drop profile analysis tensiometry equipped with a special tool for drop volume exchange during experiments. This arrangement allows investigating in the traditional way by simultaneous adsorption from a mixed solution and also by a subsequent adsorption of the protein followed by surfactant. The experiments are performed for $\beta$ casein as the protein in the presence of different amounts of the non-ionic surfactant $\mathrm{C}_{12} \mathrm{DMPO}$. The surface layers formed via the two routes show similar equilibrium surface properties. However, the dynamics of desorption of the protein complexes into the pure buffer solution deviate significantly, which is explained by the different locations of the protein/surfactant interaction. Although in both cases the complex formation is based on hydrophobic interaction, the accessibility of the hydrophobic parts of pre-adsorbed proteins due to unfolding is more favourable by the surfactant than in the solution bulk. Therefore, the amount desorbed from surface layers formed from mixed solutions is significantly less as compared to the displacement of proteins by subsequently injected surfactants interacting at the surface.
\end{abstract}

Keywords Drop profile analysis tensiometry . Adsorption kinetics · Protein surfactant mixtures

Cs. Kotsmár $(\bowtie) \cdot$ D. O. Grigoriev · A. V. Makievski · J. Krägel •

R. Miller $\cdot H$. Möhwald

Max Planck Institute of Colloids and Interfaces,

14424 Potsdam-Golm, Germany

e-mail: Csaba.Kotsmar@mpikg.mpg.de

J. K. Ferri

Department of Chemical Engineering, Lafayette College,

Easton, PA 18042, USA

\section{Introduction}

The drop profile tensiometry is presently the most versatile method for the characterisation of liquid interfaces. Since its introduction as an accurate tool for the determination of interfacial tensions and contact angle in 1983 [1], this methodology was developed extensively, as described in detail in recent monographs and reviews [2-4]. The method was further developed then to allow also dilational rheological studies, including transient [5] and low frequency harmonic relaxations [6]. Another remarkable step was made by Wege et al. [7, 8] who managed for the first time to exchange the liquid within a single pendent drop during drop shape measurements. This idea is now practiced in a number of experimental protocols, such as for desorption studies [9], penetration experiments [10], wash off studies [11] or even for multilayer formation [12].

Numerous commercial colloidal systems, mainly in the cosmetic, pharmaceutical and food industry are stabilized by mixtures of proteins and low-molecular-weight surfactants. These two types of surface active molecules show very different behaviour, regarding the adsorption mechanism, characteristic adsorption parameters as well as properties relevant for practical applications. Protein layers are used, for example, as templates for microscopic capsules, produced by chemical crosslinking of the protein structures [13] or mineralisation of protein aggregates [14]. Protein/surfactant mixtures at interfaces represent the standard situation in the process of fat digestion [15]. Mixtures of these different species can also stabilize foams or emulsions, relevant for many modern technologies, such as in food industry, coating processes and cosmetics $[16,17]$. The presence of surfactants in a protein solution can lead to a significant change of the respective surface layers or liquid films in foams and emulsions, i.e. protein molecules can be displaced by 
surfactants. Therefore, the understanding of the interaction between these two surface active species and resulting changes in the conformation of the proteins are very important. The exact mechanism for protein displacement is controversial despite extensive studies of the adsorption of protein molecules to various interfaces and their displacement by various surfactants. Different mechanisms have been invoked, such as orogenic displacement [18-21] and competitive adsorption $[22,23]$.

In the present work, we study the formation of such layer with the random coil protein $\beta$-casein and the non-ionic surfactant $\mathrm{C}_{12} \mathrm{DMPO}$; the interfacial behaviour of which is well-known. $\beta$-casein is one of the most frequently investigated model proteins [24-26] and the non-ionic alkyl dimethyl phosphine oxides represent an excellent model surfactants for fundamental investigations [27]. The formation of mixed surface layers formed by proteins and surfactants was the example studied in [18, 22, 28-31].

We will explore the formation of mixed protein-surfactant adsorption layers on two different routes. The used experimental technique is a special modification of drop profile analysis tensiometry equipped with a double coaxial capillary [7]. This arrangement allows to measure the simultaneous adsorption of both component from a mixed solution and also the subsequent adsorption of the protein first and then followed by the surfactant. Finally, the pure buffer solution can be injected into the drop in order to probe the desorption of the protein-surfactant complexes. Via a comparison of the degree of protein displacement from the interface during desorption, we will demonstrate that the location of interaction between protein and surfactant affects the kinetic irreversibility of the adsorbed complexes.

\section{Materials and methods}

The milk protein used in this study was $\beta$-casein from Sigma Aldrich (Germany; from Bovine Milk, minimum $90 \%$ pure). The solutions were prepared at $10^{-6} \mathrm{~mol} / \mathrm{l}$ in $\mathrm{pH}=7 \mathrm{Na}_{2} \mathrm{HPO}_{4} /$ $\mathrm{NaH}_{2} \mathrm{PO}_{4}$ (Fluka, assay $>99 \%$ ) $c=10 \mathrm{mM}$ buffer solution. The used water was surface chemically pure $\left(\gamma_{0}=72.0 \mathrm{mN} / \mathrm{m}\right.$ at $24{ }^{\circ} \mathrm{C}$ ) MilliQ water. The used surfactant was $\mathrm{C}_{12}$ dimethyl phosphine oxide $\left(\mathrm{C}_{12} \mathrm{DMPO}\right)$ synthesised at the MPI [27]. The solutions were prepared in a $\mathrm{pH} 7$ buffer solution using MilliQ water. For the simultaneous adsorption, we mixed respective protein and surfactant solutions and allowed $30 \mathrm{~min}$ for protein-surfactant complex formation before starting the measurements.

The surface tension measurements were performed with the drop profile analysis tensiometer PAT-1, equipped with a special Double Dosing System [7, 8, 12] (SINTERFACE Technologies, Berlin, Germany). The general setup and the details of the measuring principles are described in detail elsewhere [3]. The double dosing system with two syringes (50 $\mu$ l syringe from ILS, Germany) is connected to the double capillary (Fig. 1), which allows exchange of the bulk phase in the drop without disturbing its surface layer. The operation of the drop exchange is based on a simple masterslave principle: one syringe, connected to the inner capillary pumps small quantities of liquid into the drop, while the second syringe connected to the outer capillary controls a constant drop size, i.e. sucks excess liquid out of the drop. Thus, new liquid comes into the drop trough the inner glass capillary (1 mm diameter) and leaves the drop trough the outer plastic capillary ( $2 \mathrm{~mm}$ diameter), creating some convection/mixing. In this way, the instrument allows for example to perform adsorption experiments of different types of molecules sequentially at the same surface/interface. This methodology represents an alternative to a technique where the solutions are exchanged in the cuvette [30, 31].

\section{Results and discussion}

The curve shown in Fig. 2 shows the experimental protocol, consisting of five steps.

In step I, the dynamic surface tension is measured of a droplet formed via the outer capillary with the $\beta$-casein solution of concentration $c=10^{-6} \mathrm{M}$, which documents the adsorption kinetics up to the equilibrium reached in the plateau region in stage II. The adsorption energy of protein molecules like $\beta$-casein is very large, so that they adsorb very strongly to the surface [17]. Proteins are macromolecules containing hydrophilic and hydrophobic sites; the location of which is determined by the amino acid sequence of the protein. Once the protein reaches the interface, it will adopt a conformation in which the hydrophilic groups can interact with water and the hydrophobic parts can escape to the air phase, or into the oil phase for liquid/liquid systems [32-34]. This causes an unfolding of the molecular structure and leads to a higher adsorption energy due to the larger
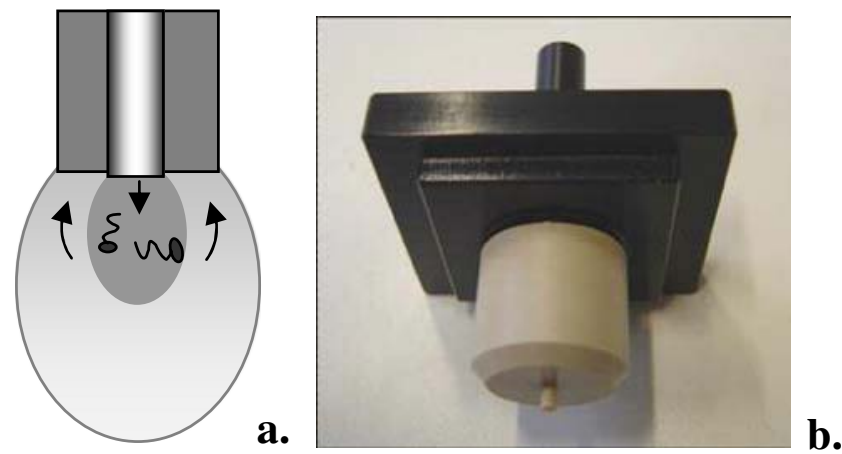

Fig. 1 a Schematic picture of the double capillary during the bulk exchange process. The new solution is pumped into the drop trough the inner capillary and sucked off simultaneously trough the outer capillary; b photo of the double capillary (SINTERFACE, Germany) 


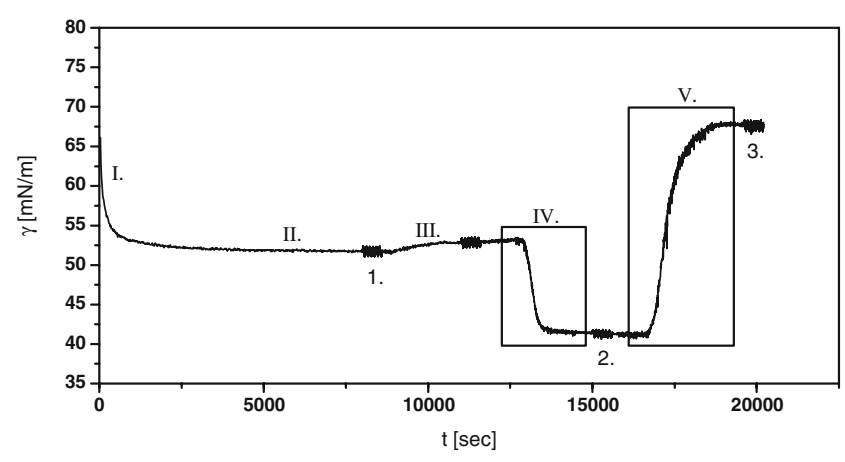

Fig. 2 Dynamic surface tensions measured for a sequential adsorption made by the coaxial double capillary: $I$ adsorption of $\beta$-casein, II equilibrium surface tension value of $\beta$-casein, 1 periodic oscillation of the drop area, III bulk exchange with buffer solution, $I V$ bulk exchange with $\mathrm{C}_{12} \mathrm{DMPO}$ solution, 2 periodic oscillation of the drop area, $V$ bulk exchange with buffer solution (washing out), 3 periodic oscillation of the drop area

number of contacts of hydrophobic parts of the protein molecule with the interface. Note that the existence of a protein layer can be probed by performing low-frequency surface layer oscillations. When the interface is covered by protein molecules, then drop surface area oscillations lead to a significant change in the surface tension due to the harmonic compression and expansion of the drop surface. In contrast, when a surfactant like $\mathrm{C}_{12} \mathrm{DMPO}$ occupies the surface layer of the drop, rather small surface tension changes are expected during area oscillations at the given concentrations due to its fast exchange of matter at a sufficiently low frequency like $0.01 \mathrm{~Hz}$ as used here. This type of experiments serves here only for a qualitative conclusion on the surface layer composition, i.e. whether the layer is mainly govern by protein or surfactant [35].

At stage III, the first exchange of the protein containing subphase against a pure $\mathrm{pH} 7$ buffer solution washes out all proteins from the drop bulk. Note that the proteins adsorbed in the surface layer obviously do not desorb but remain at the interface as the measured surface tensions remain almost constant during the subphase exchange. There is possibly a small desorption, indicated by the slightly increased surface tension. As the result, we have now a drop covered by a protein layer and containing no surface active molecules in the drop volume.

In step $I V$, a second exchange of the subphase against the $\mathrm{C}_{12} \mathrm{DMPO}$ solution at different surfactant concentrations is made. The surfactant molecules will penetrate into the protein adsorption layer modifying the surface structure and forming protein/surfactant complexes. The higher the surfactant concentration, the lower is the new surface tension plateau for the mixed adsorption layer.

In the final step $V$, a third exchange again with the buffer solution is made to check how many protein molecules are left in the adsorption layer. This exchange removed any molecules from the drop bulk. Also, the surfactants are re- moved from the drop surface due to the small adsorption energy. However, any remaining protein molecules, not displaced by the surfactant, stay in the surface layer. Increasing the concentration of the $\mathrm{C}_{12} \mathrm{DMPO}$ used for the protein displacement process leads to increasing amounts of displaced proteins, shown by higher surface tensions after this washing-off step. At the highest surfactant concentrations, we reach almost the surface tension of the pure buffer solution; hence, almost no protein is left in the surface layer. The final drop oscillations are performed to estimate the surface dilational visco-elasticity (cf. 3 in Fig. 2) as qualitative measure for the presence of protein at the interface. As there is still a measurable surface tension response, which is not expected for the pure surfactant, we have to assume that some residual protein is still adsorbed at the drop surface.

Figure 3 shows the dynamic surface tensions obtained for different surfactant concentrations by the second bulk exchange process. The higher the surfactant concentrations, the lower are the final surface tensions. We can assume that the surfactant displaces more protein molecules from the surface layer due to stronger competition. In Fig. 4, the curves are shown which correspond to the third exchange (washing out) of the previously injected $\mathrm{C}_{12} \mathrm{DMPO}$ molecules.

From equilibrium surface tension values for the mixed layers, we constructed the isotherm (circles) in Fig. 5 and compared it with the isotherm of pure $\mathrm{C}_{12} \mathrm{DMPO}$ (squares). One can see that the two curves are almost identical at concentrations above $8 \cdot 10^{-5} \mathrm{~mol} / \mathrm{l}$, which means that at these higher concentrations, the surfactant replaced at least a significant part of the adsorbed proteins from the surface, so that finally only surfactants are left at the surface (region C). On the contrary, almost nothing happens with the protein layer in region $\mathrm{A}$, i.e. at lowest $\mathrm{C}_{12} \mathrm{DMPO}$ concentrations. The solid horizontal line is the equilibrium surface tension

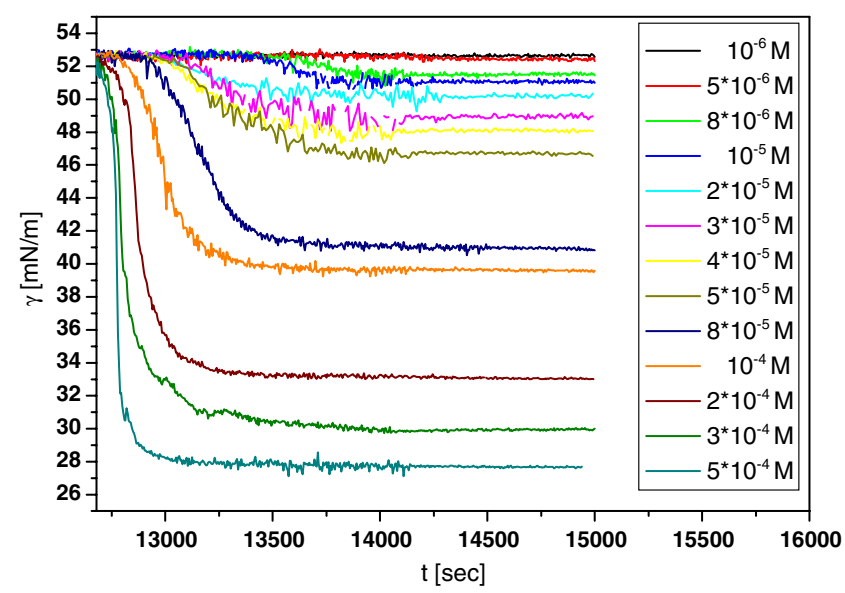

Fig. 3 Dynamic surface tensions during the drop-bulk exchange process measured for sequential adsorption experiments with different $\mathrm{C}_{12} \mathrm{DMPO}$ concentrations (from $10^{-6} \mathrm{M}$ up to $5^{*} 10^{-4} \mathrm{M}$ ) at a fixed $\beta$ casein concentration of $10^{-6} \mathrm{~mol} / \mathrm{l}$ 


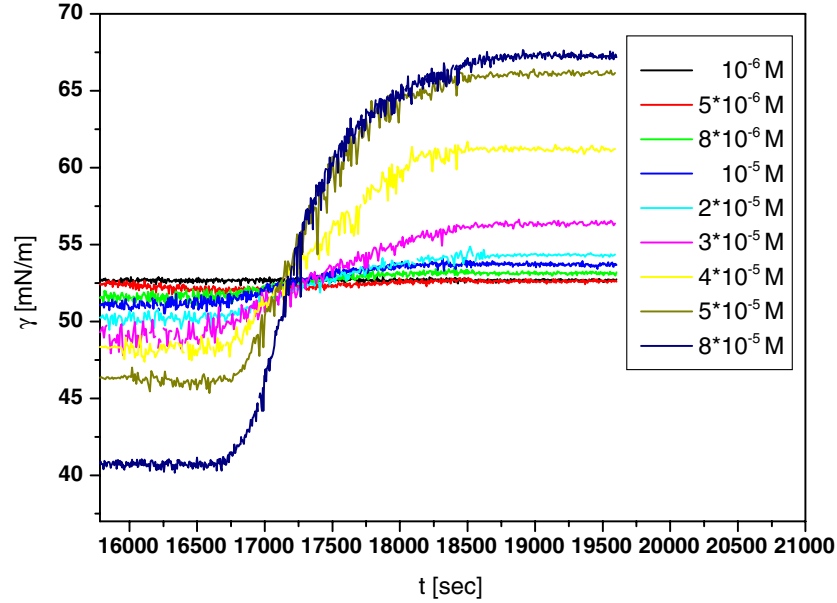

Fig. 4 Dynamic surface tensions measured during the drop-bulk exchange processes after sequential adsorption experiments at different concentrations of $\mathrm{C}_{12} \mathrm{DMPO}$ solutions and subsequently exchange with a buffer solution (washing out); all experiments were performed at an initial $\beta$-casein concentration of $10^{-6} \mathrm{~mol} / 1$

value of the pure $\beta$-casein solution. In region $B$, a transition from one situation into the other is observed, so that we have a real mixed layer formed by protein and surfactant molecules.

The third curve in Fig. 5 (triangles) represents the results for simultaneous competitive adsorption experiments. One can see that the two curves are essentially the same. It seems that the way how mixed protein-surfactant layers are formed does not play a decisive role on the equilibrium surface layer properties.

The equilibrium state of the adsorption layers shown in Fig. 5 was used so far to explain changes in the mixed ad-

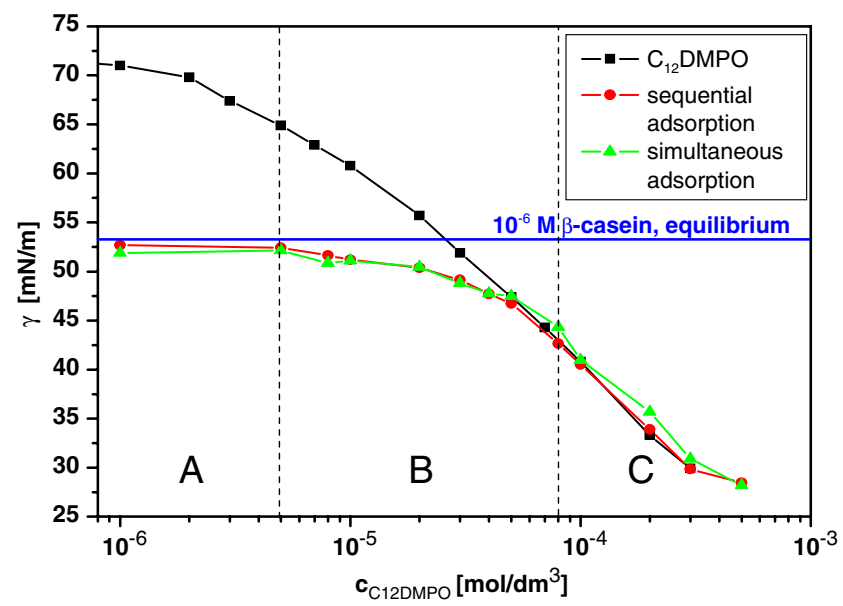

Fig. 5 Surface tension isotherm of $\mathrm{C}_{12} \mathrm{DMPO}$ (squares); equilibrium surface tension values for the mixed layers measured for the sequential adsorption experiments after the drop-bulk exchange at different concentrations of $\mathrm{C}_{12} \mathrm{DMPO}$ (circles) and for simultaneous competitive adsorption experiments (triangles)

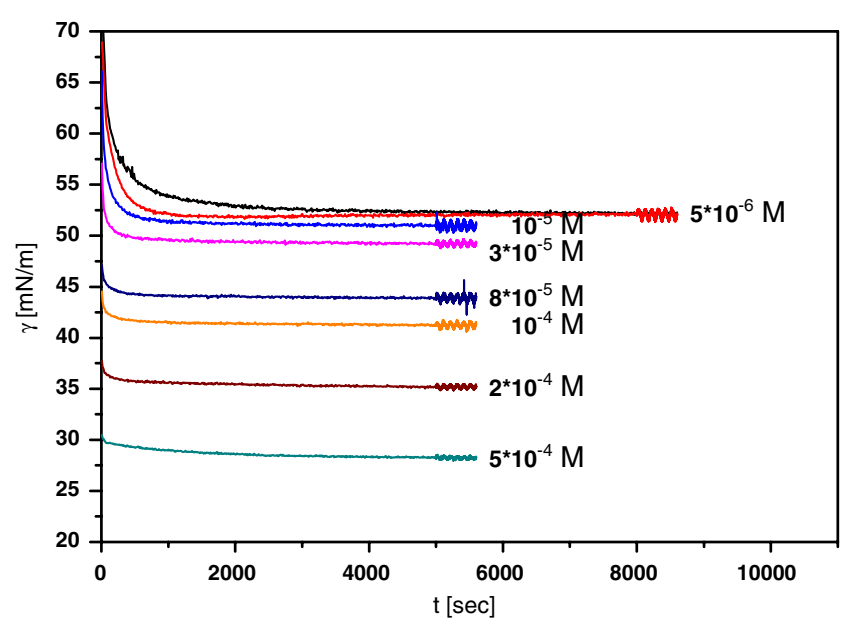

Fig. 6 Dynamic surface tension measured for simultaneous adsorption from a mixed solution of $\beta$-casein and $\mathrm{C}_{12} \mathrm{DMPO}$ at different $\mathrm{C}_{12} \mathrm{DMPO}$ concentrations and fixed $\beta$-casein concentration of $10^{-6} \mathrm{~mol} / 1$

sorption layer. We can, however, also qualitatively compare the kinetics of adsorption measured by the dynamic surface tensions in the sequential and simultaneous adsorption protocols (Fig. 6). One can see that the displacement of the protein molecules by the surfactant requires a relatively long time, decreasing with increasing surfactant concentration. However, even at the highest concentration of $510^{-4} \mathrm{M}$ used here (Fig. 3), the process lasts about $600 \mathrm{~s}$. On the contrary, the simultaneous adsorption from mixed solutions is by orders of magnitude faster. A quantitative description for both adsorption protocols requires modification of the available theoretical models [28].

To analyse if the route of adsorption layer formation has impact on the protein displacement, we performed also wash-

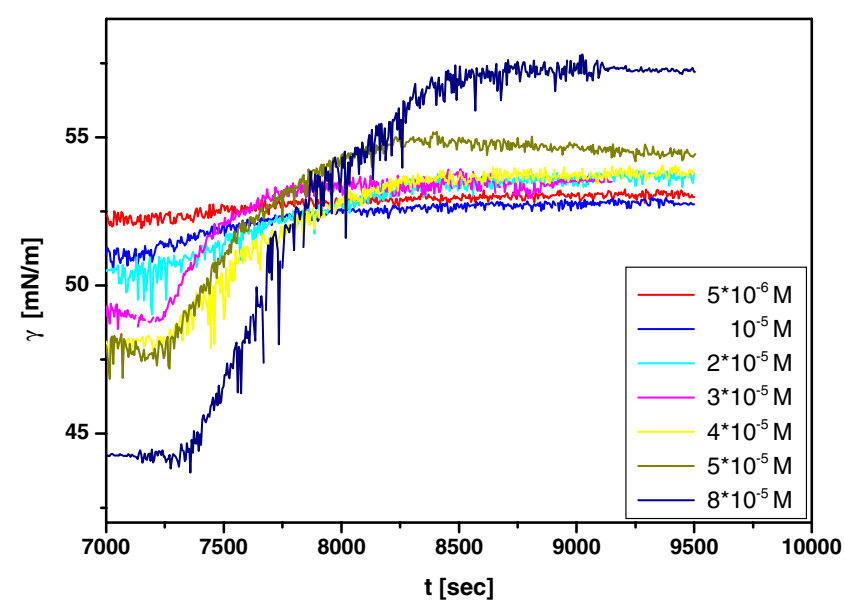

Fig. 7 Dynamic surface tensions measured during the drop-bulk exchange process with buffer solution (washing out) after simultaneous adsorption experiments with different $\mathrm{C}_{12} \mathrm{DMPO}$ concentrations and fixed $\beta$-casein concentration of $10^{-6} \mathrm{~mol} / \mathrm{l}$ (given in Fig. 6) 
off experiments for adsorption layers formed from a mixed protein-surfactant solution. The results shown in Figs. 6 and 7 demonstrate that there are remarkable differences for the two ways of mixed adsorption layer formation, which depend obviously on where the protein-surfactant complexes are formed - in the bulk as it occurs by the simultaneous adsorption experiments or in the surface layer during sequential adsorption experiments.

One of the possible mechanisms for the displacement of proteins by surfactants was proposed by Mackie and coworkers [36] and named 'orogenic' displacement. Surfactant molecules penetrate initially into the holes left in the protein network and adsorb at the interface. At higher surfactant bulk concentration, the amount of penetrated surfactant molecules increases and at a certain surfactant concentration, the rigidity of protein network breaks off due to the reached high surface pressure. This process leads then to a gradual displacement of the protein molecules from the surface into the bulk.

An alternative mechanism would be based on the formation of protein-surfactant complexes. The used surfactant $\mathrm{C}_{12}$ DMPO is uncharged, so that the interaction with the protein is of a hydrophobic nature. In contrast, ionic surfactants can additionally interact electrostatically with the protein molecules, depending on their net charge [37]. In both cases, the interaction leads to respective conformational changes of the protein molecules.

For the simultaneous adsorption shown in Fig. 6, the kinetics is rather fast and corresponds essentially to a competitive process of two compounds. The faster single surfactants, not bound to the protein, can adsorb just following the general diffusion mechanism, and the protein-surfactant complexes provide some additional effects. With increasing surfactant concentration, the resulting complexes become less and less surface active and hence become of secondary importance for the adsorption layer formation. The kinetic curves observed for the sequential adsorption are of course different. Here, in the beginning, we have an established protein layer at the surface and the $\mathrm{C}_{12} \mathrm{DMPO}$ can diffuse from the solution to the surface but cannot adsorb easily. The surfactant molecules rather start interaction with the adsorbed protein molecules and form protein-surfactant complexes at the interface. The interaction is again controlled by the hydrophobic parts of the surfactant and the protein. Through this protein-surfactant interaction, the proteins change their conformation and become less surface active, are increasingly easier desorbed, and the free surfactants occupy and govern the surface layer, in agreement with the results discussed in [38]. This is why, at higher surfactant concentrations, the surface layer contains only or almost only surfactant molecules. A quantitative analysis of the two sets of dynamic surface tensions, given in Figs. 3 and 6, respectively, requires adequate theoretical models which have been derived in general but have to be refined for the present situation. This work is presently under way.

Let us see the observed results in the light of the mechanism called 'orogenic displacement' [19-21, 36]. For the simultaneous adsorption protocol, we can state that it cannot be applied, as the adsorbing species are the proteinsurfactant complexes and free surfactant molecules, which simply adsorb in a competitive manner. For the case of sequential adsorption, it is obviously the hydrophobic interaction between protein and surfactant molecules meeting at the interface. This interaction leads to complexes of surface activity lower than the original protein and to a successive displacement from the interface due to competition. In an 'orogenic displacement' process, the interaction between nonionic surfactants and proteins leads to a break-off of a preformed protein layer, leading to patches which are then displaced by gravity from the interface and precipitate into the bulk. However, again the surfactants would first have to hydrophilise these patches to make them wetted by the aqueous solution bulk. Hence, we can conclude that for cross-linked protein layers formed at higher bulk concentration, the orogenic mechanism plus hydrophilisation via hydrophobic interaction with the surfactant is more of a problem, while for protein layers of cross-linked interfacial structure the molecular mechanism seems to be sufficient to explain the observed results.

Inspection of Figs. 4, 7 and 8 shows that there are significant differences in the dynamic surface tension data after washing with a $\mathrm{C}_{12} \mathrm{DMPO}$ solution and subsequently by the pure buffer solution. After sequential adsorption, where the complexes are formed in the adsorption layer, the surface tension reaches much higher values, i.e. the protein/

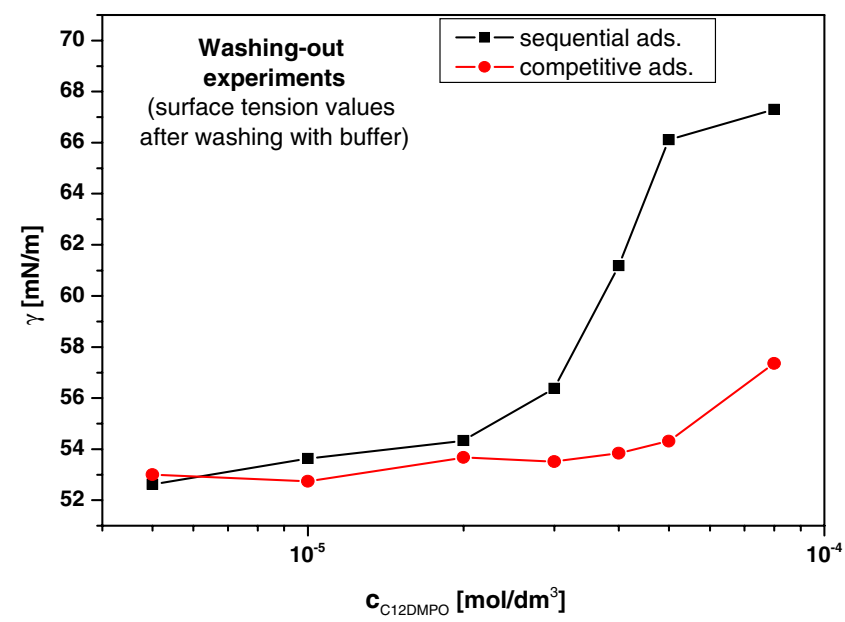

Fig. 8 Equilibrium surface tensions measured after drop-bulk exchange processes with different $\mathrm{C}_{12} \mathrm{DMPO}$ concentrations and subsequently with pure buffer solution (washing out) after sequential adsorption experiments (squares) and after simultaneous adsorption experiments (circles); all experiments were performed at a fixed $\beta$ casein concentration of $10^{-6} \mathrm{~mol} / \mathrm{l}$ 
surfactant complexes can be displaced by the surfactant much easier than those formed already in the bulk. Hence, the nature and the structure of the two types of complexes must be different. The reason can be that proteins in the sequential adsorption experiments are already unfolded at the surface, expose more hydrophobic parts, and in this modified structure consequently more surfactant molecules can bind. In the other case, the proteins have a more compact structure in the bulk and more hydrophobic segments are hidden in the core and cannot interact with the surfactants. These complexes will later adsorb and bind to the surface via the more remaining hydrophobic parts, i.e. with higher adsorption energy.

\section{Conclusions}

The adsorption of the non-ionic surfactant, $\mathrm{C}_{12} \mathrm{DMPO}$ can cause a breakdown of a pre-adsorbed protein ( $\beta$-casein) layer. At higher surfactant concentrations, the proteins can be displaced from the adsorption layer. The displacement is most probably due to the interaction between protein and surfactant, leading to a decreased surface activity of the resulting complexes as compared to the pure protein, and hence to a more successful competitive adsorption for free surfactants.

The mixed protein-surfactant layers built up in two different ways, sequentially and by simultaneous adsorption, show a similar equilibrium state, i.e. the way of the build-up does not significantly influence the equilibrium properties of the surface layer. In contrast, there are significant differences in the desorption kinetics. The washing-out experiments show that the structures of the adsorption layers in reality are different for the two ways of their formation, depending on where the protein-surfactant complexes are formed. When the two components interact already in the bulk, the simultaneous adsorption is a competitive adsorption between complexes and free surfactants, and with increasing surfactant concentration simply less complexes can adsorb.

In the sequential adsorption experiments, complexes are formed in the surface layer only, and the number of surfactant molecules competing with the pre-adsorbed proteins is larger and hence the efficiency of replacing them from the interface is larger.

In order to be able to learn more about the structure of the formed complexes between proteins and surfactants, spectroscopic experiments such as IRRAS and interfacial CD would provide more details information. Such studies are presently under way.
Open Access This article is distributed under the terms of the Creative Commons Attribution Noncommercial License which permits any noncommercial use, distribution, and reproduction in any medium, provided the original author(s) and source are credited.

\section{References}

1. Rotenberg Y, Boruvka L, Neumann AW (1983) J Colloid Interface Sci 93:169

2. Chen P, Kwok DY, Prokop RM, del Rio OI, Susnar SS, Neumann AW (1998) In: Möbius D, Miller R (eds) Studies in interface science, vol. 6. Elsevier, Amsterdam, p 61

3. Loglio G, Pandolfini P, Miller R, Makievski AV, Ravera F, Ferrari M, Liggieri L (2001) In: Möbius D, Miller R (eds) Studies in interface science, vol. 11. Elsevier, Amsterdam, p 439

4. Hoorfar M, Neumann AW (2006) Adv Colloid Interface Sci 121:25

5. Miller R, Sedev R, Schano KH, Ng CH, Neumann AW (1993) Colloids Surf A 69:209

6. Benjamins J, Cagna A, Lucassen-Reynders EH (1996) Colloids Surf A 114:245

7. Cabrerizo-Vilchez MA, Wege HA, Holgado-Terriza JA (1999) Rev Sci Instrum 70:2438

8. Wege HA, Holgado-Terriza JA, Neumann AW, Cabrerizo-Vilchez MA (1999) Colloids Surf A 156:509

9. Ferri JK, Gorevski N, Kotsmar Cs, Leser ME, Miller R (2008) Colloids Surf A: Physicochem Eng Aspects 319:13-20

10. Ganzevles RA, Zinoviadou K, van Vliet T, Cohen Stuart MA, de Jongh HHJ (2006) Langmuir 22:10089

11. Fainerman VB, Miller R, Ferri JK, Watzke H, Leser ME, Michel M (2006) Adv Colloid Interface Sci 123-126:163

12. Ferri JK, Dong WF, Miller R (2005) J Phys Chem B 109:14764

13. Russell JT, Lin Y, Böker A, Su L, Carl P, Zettl H, He J, Sill K, Tangirala R, Emrick T, Littrell K, Thiyagarajan P, Fery A, Wang Q, Russell TP (2005) Angew Chem Int Ed 44:2420

14. Hermanson KD, Harasim MB, Scheibel T, Bausch AR (2007) Phys Chem Chem Phys 9:6442

15. Reis P, Holmberg K, Miller R, Krägel J, Grigoriev DO, Leser ME, Watzke H (2008) Langmuir (in press)

16. Dickinson E, Rodriguez Patino JM (eds) (1999) Food emulsions and foams. Interactions and stability, Special Publication No. 227, Royal Society of Chemistry

17. Bos MA, van Vliet T (2001) Adv Colloid Interface Sci 91:437

18. Mackie AR, Gunning AP, Ridout MJ, Wilde PJ, Morris VI (2001) Langmuir 17:6593

19. Gunning PA, Mackie AR, Gunning AP, Wilde PJ, Woodward NC, Morris VJ (2004) Food Hydrocoll 18:509

20. Rereira LGC, Theodoly O, Blanch HW, Radke CJ (2003) Langmuir 19:2349

21. Freer EM, Yim KS, Fuller GG, Radke CJ (2004) J Phys Chem B 108:3835

22. Miller R, Fainerman VB, Leser ME, Michel M (2004) Colloids Surf A 233:39

23. Fainerman VB, Leser ME, Michel M, Lucassen-Reynders EH, Miller R (2005) J Phys Chem B 109:9672

24. Miller R, Fainerman VB, Aksenenko EV, Leser ME, Michel M (2004) Langmuir 20:771

25. Maldonado-Valderrama J, Gálvez-Ruiz MJ, Marín-Rodriguez A, Cabrerizo-Vílchez MA (2005) Colloids Surf A 270-271:323 
26. Maldonado-Valderrama J, Martin-Molina A, Martin-Rodriguez A, Cabrerizo-Vilchez MA, Galvez-Ruiz MJ, Langevin D (2007) J Phys Chem C 111:2715

27. Lunkenheimer K, Haage K, Miller R (1987) Colloids Surf 22:215

28. Miller R, Fainerman VB, Leser ME, Michel M (2004) Curr Opin Colloid Interface Sci 9:350

29. Sanchez CC, Fernandez MC, Rodriguez Nino MR, Rodriguez Patino JM (2006) Langmuir 22:4215

30. Svitova TF, Wetherbee MJ, Radke CJ (2003) J Colloid Interface Sci 261:170

31. Fainerman VB, Lylyk SV, Ferri JK, Miller R, Watzke H, Leser ME, Michel M (2006) Colloids Surf A 282-283:217
32. Gunning PA, Mackie AR, Gunning AP, Wilde PJ, Woodward NC, Morris VJ (2004) Food Hydrocoll 18:509

33. Mackie AR (2004) Curr Opin Colloid Interface Sci 9:357

34. Rippner Blomqvist B, Ridout MJ, Mackie AR, Wärnheim T, Claesson PM, Wilde P (2004) Langmuir 20:10150

35. Aksenenko EV, Kovalchuk VI, Fainerman VB, Miller R (2006) Adv Colloid Interface Sci 122:57

36. Mackie AR, Gunning AP, Wilde PJ, Morris VI (1999) J Colloid Interface Sci 210:157

37. Fainerman VB, Zholob SA, Leser ME, Michel M, Miller R (2004) J Phys Chem 108:16780

38. Fainerman VB, Zholob SA, Leser ME, Michel M, Miller R (2004) J Colloid Interface Sci 274:496 